DANDELION

postgraduate arts journal \& research network

VOLUME TWO NUMBER ONE SPRING 2011
DR DiAne SilverthorNe is a specialist in fin-de-siècle art and design, particularly Viennese, and in modernism, art, and music. She lectures in the History of Art and Screen Media Department at Birkbeck, and the Institute of Germanic and Romance Studies, University of London. Her doctoral thesis, New Spaces of Art, Design and Performance: Alfred Roller and the Vienna Secession 1897 1905, considered concepts of space and notions of the Gesamtkunstkwerk (total work of art) in the applied arts.

\title{
Project Review
}

\author{
'The Viennese Café and Fin-de-Siècle Culture' \\ A collaboration between The Royal College of Art and Birkbeck, led by \\ Professor Jeremy Aynsley (RCA), Dr Tag Gronberg (Birkbeck) and \\ Professor Simon Shaw-Miller (Birkbeck), Funded by the Arts and \\ Humanities Research Council (AHRC), 2006-09
}

\section{Diane Silverthorne}

ON A BRIGHT MORNING IN OCTOBER 2008, the doors of the Royal College of Art opened to an unusual exhibition. Instead of the cutting-edge art more usually associated with RCA students and their final-year shows, a modified version of the long-established Viennese café, Demel, was installed at the entrance. Inside the exhibition sound recordings, film, and a series of reproductions of various Viennese coffeehouse settings from the eighteenth century onwards explored the café as a social, designed, and cultural space. Within hours of opening, the exhibition spaces were crowded with members of the public, as well as of the academic community, and remained so throughout the two weeks of the exhibition's life. Many stayed, often for several hours, treating the makeshift coffeehouse tables as 'a sort of democratic club [...] where every guest can sit for hours on end, discussing', as Viennese writer Stefan Zweig described in his autobiography. ${ }^{1}$ Visitors were cast in a performative role, apparently recreating the famously interconnected creative circles of Vienna café life at the turn of the twentieth century. The talk was often of memory, mediated through the images of the coffeehouses, particularly amongst members of the Viennese community living in London. 


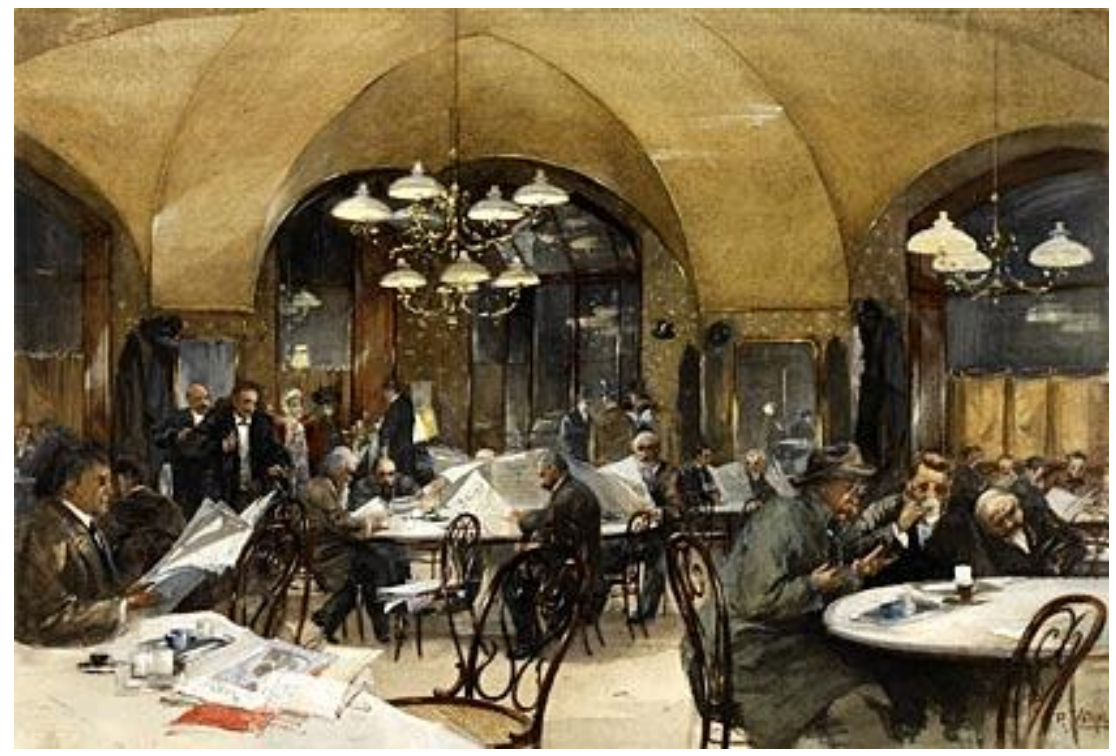

Fig. I: Reinhardt Völkel, In Café Grienstadl, 1896

The exhibition, together with a series of planned events including readings, chamber concerts exploring the music of the second Viennese School, and film screenings_notably The Third Man (1949) and Café Electric (1927), directed by Gustav Ucicky, the son of artist Gustav Klimt—-took place midway through the three-year, AHRC-funded project. $^{2}$ A two-day international academic conference, 'The Viennese Café as an Urban Site of Cultural Exchange', attracted contributions from established Vienna cultural historians as well as emerging scholars from the UK, Europe, and the USA, and an audience of knowledgeable and informed members of the public, a stated aim of the project. Keynote papers were given by cultural historian Steven Beller, who has written extensively on the complexities of Vienna and Jewish identity, and Edward Timms, whose contribution to an understanding of Viennese modernism includes his work on polemicist Karl Kraus, editor of the satirical periodical, Die Fackel [The Torch], and a period described apocryphally by Kraus as 'the last days of mankind'.

Given the richness and diversity of the programme it was billed as the 'Vienna 1900 Café Festival', a theme reflected in the ensuing coverage in the London media. This review briefly considers these various events and the project's aims: to open up the field of Viennese and Austrian studies, and to find new points of contact from different fields of research.

The project was designed to raise a series of questions challenging the dominant discourse of urban modernism and art history centred on Paris. Instead of the notion of modernity personified in the figures of the flâneur and the 'painter of modern life', and the spectacle of Haussmann's boulevards, the construction of fin-de-siècle Vienna as the birthplace of modernism relies on the centrality of the coffeehouse and its more static, interior spaces as a site of exceptional and parallel developments in the fine and applied arts, music, literature, philosophy, and psychoanalysis. A focus on the interior urban space of the coffeehouse, it was argued, provided a seemingly more private, but no 
less complex lens through which to understand urban modernity. ${ }^{4}$ The coffeehouse space was not fixed but rather permeable, in constant dialogue with external events and other cultural spaces, no less so than through the proliferation of European newspapers, literary and art periodicals. Its informality permitted the transgressive crossing of social and political boundaries, which were upheld more formally and conservatively in other spheres of Vienna's public life.

Unlike Haussmann's Paris, spatial dissonance, rather than structural consonance, or coherence, was a dominant feature of Vienna's mid-nineteenth century urban redevelopment, centred on the city's Ringstrasse, and a series of monumental, individually-styled, historicist buildings, constructed in the name of liberal enlightenment. In contrast, the interior design of Vienna's central coffeehouses reflected standardisation, uniformity, and cosiness (a quality much prized by modernist architect Adolf Loos), offering a familiar 'home from home'.

Instead of the long nineteenth century of France's fin-de-siècle, the birth of modernism in Vienna has been characterised as a period of intense temporal compression. The signs and effects of modernity were experienced and expressed in a shorter time period and under greater pressure than other European cities. Modern movements appeared in the 1890s, and were fully matured two decades later. The effect of this compression of time and space predicates a study of fin-de-siècle Vienna on an interdisciplinary model, advocated by cultural historian Carl E. Schorske in his pioneering work on this subject, Fin-de-siècle Vienna: Politics and Culture. ${ }^{5}$ The culturally-charged, but academically-neutral coffeehouse space represents a discursive field of study owned by no single academic discipline, but shared by several. ${ }^{6}$

The imposition of a broad theme such as this for doctoral research is a necessary condition of an AHRC project. My thesis touched on, but did not further develop the theme of the Vienna café. Instead, it investigated a series of seemingly disparate but interconnected aesthetic spaces - the art periodical, the exhibition, and the stage-contributing to the construction of modernity in the visual arts in fin-de-siècle Vienna, viewed through the practices of a lesserknown Secession artist, Alfred Roller (1864-1935). ${ }^{7}$ This fruitfully led to a more expansive interpretation of the 'spaces' of cultural production.

Mirroring Schorske's inter-disciplinary model, the academic board members for the project were drawn from the disciplines of art and design histories, musicology and architecture. Given this structure, it is perhaps surprising that, other than supervision, no formal process existed to facilitate a cultural exchange between panel members and PhD candidate. Nevertheless, such exchanges happened serendipitously. The presence of musicologist $\mathrm{Dr}$ Amanda Glauert, for example, afforded me the opportunity to explore in depth the convergence of modernist design and music in an all-Lieder issue of Ver Sacrum [Sacred Spring] (1898-1903), the Vienna Secession art periodical. Informal conversations led to our collaborative staging of a 'small Gesamtkunstwerk' [total work of art] in the Piano Gallery at the Royal Academy of Music, during the Festival fortnight. ${ }^{8}$ The event examined, in the words of musicologist Walter Frisch, not what Jugendstil [youth style] had done for 
music, but what music had done for Jugendstil, and Vienna's modernist design, illustrated through visual analysis and live performance of the Lieder. ${ }^{9}$

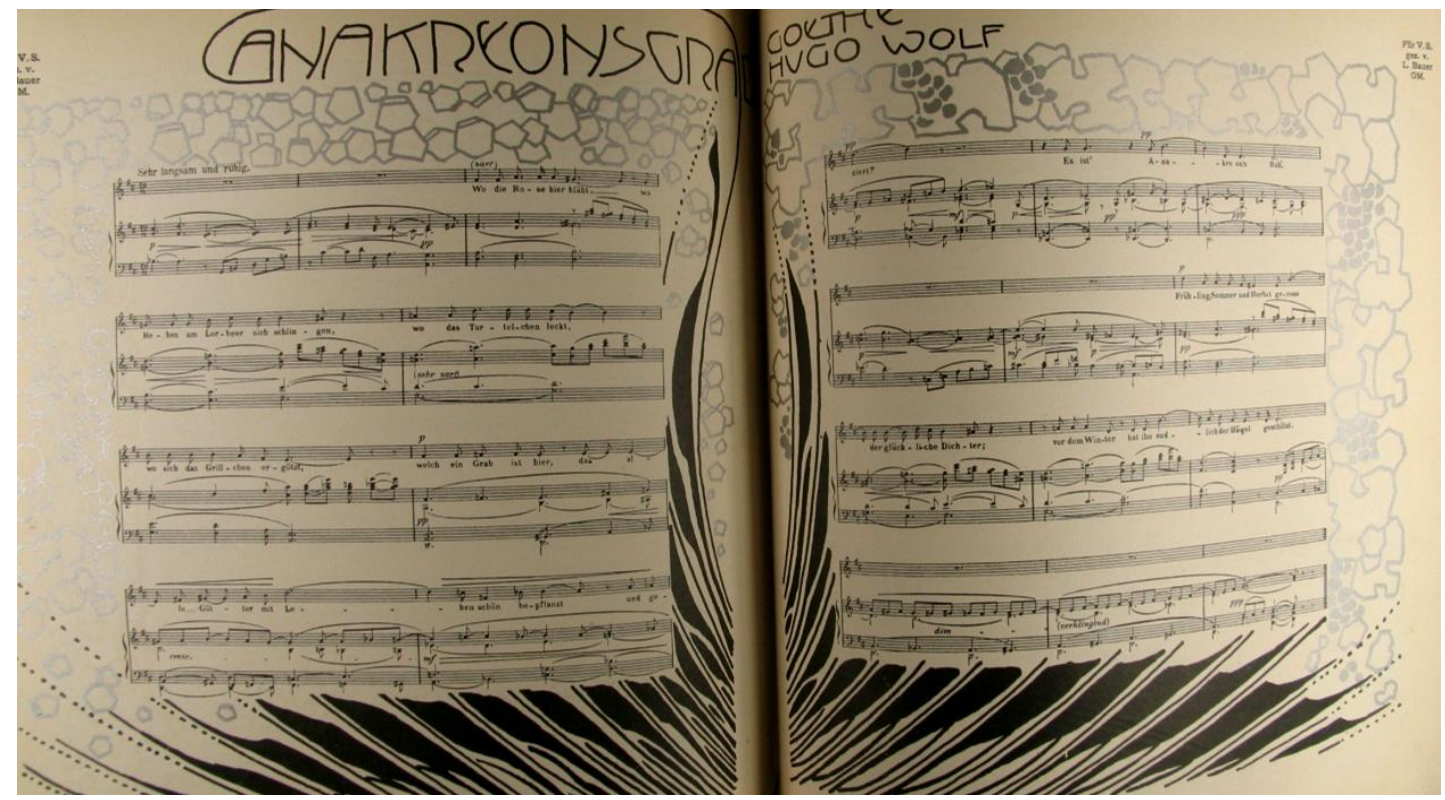

Fig. 2: Lied composed by Hugo Wolf, Ver Sacrum, Dec. I 901 [photograph: author]

Recent literature has argued that Vienna's spaces of interiority, seemingly impermeable and enclosed, were in constant dialogue with the liminal spaces between the city and the surrounding countryside, and the further reaches of the Habsburg Empire. Rather than treating Vienna and the coffeehouse as a world unto itself, the project's conference took a more panoramic view. ${ }^{10}$ Beller's keynote paper, 'The Jew Belongs in the Coffeehouse', explored the question of the Viennese café as a Jewish space within the city. The nature of the coffeehouse, as a space of social interaction, shared with the Jews the status of not being 'of this ground'. Cafés were at the heart of the city, but outside its formal institutions, like the Jews, who, despite their prominence, were also regarded as outsiders. Sachar Pinsker (University of Michigan) in a paper titled 'Between "The House of Study" and the Kaffeehaus', considered the previously unexplored role of the coffeehouse in the emergence of Hebrew and Yiddish modernism, shifting the focus geographically from Vienna to Berlin and Lemberg (Lvov), and back. Ines Sabotic (Institute of Social Sciences Ivo Pilar), set out to determine similarities and differences between Zagreb and Vienna, the periphery and the centre, and the café as a construction of Croatian identity. Kasia Murawska-Muthesius (Birkbeck) chose a case study, Michalik's Den in Krakow, to explore the medium of caricature as transgressive and ephemeral, and a source of the construction of modern urban Jewish and female identity. My own paper provided evidence, rather than well-worn anecdote, of the extent to which the early plans of the Vienna Secession were formulated in a Vienna café in 1897, as revealed in Roller's personal notebooks, leading to a series of spectacular 'set-pieces'-the building of the Secession House and a series of avant-garde exhibitions-which rejuvenated Vienna's 
visual arts. Gilbert Carr (Trinity College, Dublin) characterised the Vienna coffeehouse as an intellectualised, psychic space, a construction of the collective memory of the inter-war period. This pointed to a central issue presented by the subject matter of the conference, which, as Carr described, turns on a 'nostalgic discourse of reminiscence', and an inevitable overlapping of concerns common to all the papers. Nevertheless, most broke through Vienna's spaces of interiority to reveal views onto a potentially vast and radically different terrain.

Harold B. Segel has described the Vienna café as a miniature stage, its leading players, artists and intellectuals, the onlookers their audience. ${ }^{11}$ No such hierarchies appeared to prevail through the duration of the exhibition, and the variously inter-connected spaces of performance during the Vienna Café Festival. Like the mythicized spaces of Vienna's fin-de-siècle coffeehouses, the Vienna café, as metaphor, paradigm and as physical space, brought together scholars from disparate academic fields for 'coffee and conversation' to create a truly interdisciplinary exchange. Similarly, the private, sometimes hermetic world of academia was brought into fruitful dialogue with the public, thus fulfilling a founding research objective of this AHRC project. From public exhibition and conference to doctoral research, the project reflected a commitment to a system of enquiry predicated on the diachronic and the synchronic: the interrogation of the text with respect to tendencies prevailing in its own field, and other branches of culture at the same time. It would be difficult to say to what extent the excellence of Demel's celebrated coffee and cheesecake contributed to this synthesis.

\section{Birkbeck College, University of London}

\section{Notes}

1. Stefan Zweig, The World of Yesterday: An Autobiography (Lincoln, NE and London: University of Nebraska Press, 1964), p. 39.

2. $\quad<$ http://viennacafe.rca.ac.uk/events.html > [accessed 2 January 2011].

3. Steven Beller, Vienna and the Jews, 1867-1938: A Cultural History (Cambridge: Cambridge University Press, 1989); Edward Timms, Karl Kraus, Apocalyptic Satirist: Culture and Catastrophe in Habsburg Vienna (London: Yale University Press, 1986). The phrase 'the last days of mankind' is taken from the title of Kraus's satire of the First World War, Die letzen Tage der Menscheit, see Timms, pp. 3, 369-402.

4. See Charlotte Ashby, 'Introduction', in The Viennese Café and Fin-de-siècle Culture, ed. by C. Ashby, T. Gronberg, and S. Shaw-Miller (Oxford: Berghahn, forthcoming).

5. Carl E Schorske, Fin-de-siècle Vienna: Politics and Culture (New York: Vintage, 1981), pp. xvii-xxii.

6. See, for example, Allan S. Janik and Hans Veigl, Wittgenstein in Vienna: A Biographical Excursion Through the City and its History (Vienna and New York: Springer, 1998);

Markman Ellis, The Coffee House: A Cultural History (London: Weidenfeld and Nicholson, 2005); Christoph Grafe and Franziska Bollerey, Cafés and Bars: The Architecture of Public Display (Abingdon: Routledge, 2007); Tag Gronberg, Vienna: City of Modernity 1890-1914 (Oxford and Bern: Peter Lang, 2007).

7. Diane Silverthorne, 'New Spaces of Art, Design and Performance: Alfred Roller and the Vienna Secession 1897-1905', doctoral thesis, Royal College of Art, London, June 2010. Roller is best known as stage designer at the Vienna Court Opera during the Mahler years. 
8. Amanda Glauert, Hugo Wolf and the Wagnerian Inheritance (Cambridge: Cambridge University Press, 1999), also for Wolf as the protagonist of 'the small Gesamtkunstwerk', p. 32.

9. Walter Frisch, German Modernism: Music and the Arts (London: University of California, 1990), particularly pp. 88-137.

10. See Scott Spector, 'Marginalisations: Politics and Culture beyond Fin-de-Siècle Vienna', in Rethinking Vienna 1900, ed. by Steven Beller, Austrian Studies V. 3 (Oxford: Berghahn, 2001), pp. 132-53, for this interpretation.

11. The Vienna Coffeehouse Wits, 1890-1939, ed. by Harold B. Segel (West Lafayette, IN: Purdue University Press, 1993), p. 12. 